\title{
BARNABAS OR SAUL: WHO IS DESCRIBING SAUL'S CONVERSION IN ACTS 9:27?
}

\author{
Mark Wilson \\ Old and New Testament \\ Stellenbosch University
}

\begin{abstract}
This article examines a problem of translation in Acts 9:27 regarding who should be the subject of the sentence - Barnabas or Saul. Through a close examination of the Greek text in its broader pericope, it explores whether Barnabas was the one who told the apostles in Jerusalem about Saul's conversion. It also discusses the importance of eyewitness testimony to Luke in his Gospel and Acts. The article closes with a fresh observation about the conversion account's significance within the narrative structure of Acts.
\end{abstract}

Key Words: Barnabas; Saul; Eyewitness Testimony; Conversion

\section{Introduction}

In his 2010 article entitled "The Role of Barnabas in the Book of Acts," Murphy discusses Paul's conversion in Acts 9 wherein "Barnabas is portrayed in the narrative not only as an advocate for Saul but also as an intermediary between him and the people. Barnabas told the apostles of Saul's encounter with the Lord as well as his courageous proclamation of Jesus in Damascus. Barnabas used his relationship with the apostles to speak up for Saul."1 This article will explore whether it was indeed Barnabas who told the apostles about Saul's conversion, by examining afresh the text in Acts 9:26-28. Introduced into the discussion is the significance of eyewitness testimony in antiquity as it relates to the early church. The article will close with a fresh observation about the account's contribution to the narrative structure of Acts.

\section{Barnabas in Acts}

Joseph, called Barnabas by the apostles, is introduced in Acts 4:36-37 as a Levite from Cyprus. He generously sold a piece of land to provide for the needs of the nascent community of believers, unlike Ananias and Sapphira whose parsimonious dissimulation follows. Luke's depiction of Barnabas in the early chapters of Acts, according to Bonneau, functions in two ways: he is a model for the community and he is a model for all the believers. ${ }^{2}$ The first thirty verses of Acts chapter 9 present the account of Saul's conversion. The pericope ends with his escape from Damascus and his return to Jerusalem. The church there is skeptical about the arrival of this interloper who had formerly persecuted them. Barnabas lived up to his appellation as "Son of Encouragement" and introduced Saul to the

S Jonathan Murphy, "The Role of Barnabas in the Book of Acts," Bibliotheca Sacra 167, July-September 2010:323.

2 Guy Bonneau, "Le Fils du réconfort: La construction du personnage de Barnabas dans les Actes," in Analyse Narrative et Bible C Focant and A Wénin (eds.); Leuven: Leuven University Press, 2005:316-17; French text: "Un modèle la communauté de Luc" and "Un modèle pour tous les croyants." 
apostles. ${ }^{3}$ The apostles were now told the account of Saul's conversion on the road to Damascus.

\section{Who is the Storyteller?}

But is it Barnabas or Saul who is telling the story? The Greek text of 9:27 is ambiguous:

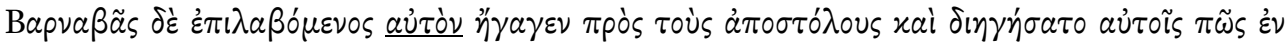

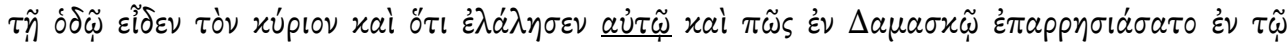

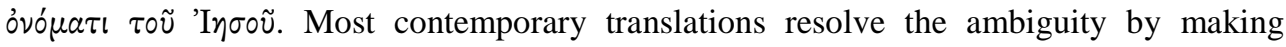
Barnabas either the implicit or explicit subject of $\delta \eta \eta \gamma \dot{\sigma} \sigma \tau$. For example, the NIV reads: "But Barnabas took him and brought him to the apostles. He told them how Saul on his journey had seen the Lord..." The NLT translation reads similarly. The ESV translates: "But Barnabas took him and brought him to the apostles and declared to them how on the road he had seen the Lord..." The KJV, NASB, and NRSV read similarly to the ESV in their translations. Only the NKJV translation provides a more literal translation by preserving the ambiguity in the Greek text: "But Barnabas took him and brought him to the apostles. And he declared to them how he had seen the Lord on the road...."

So is Barnabas or Saul the subject of $\delta i \eta \gamma \eta \dot{\sigma} \alpha \tau$ ? A look at the broader pericope can perhaps provide a clue:

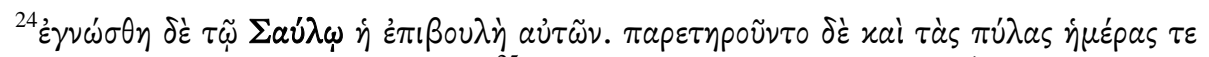

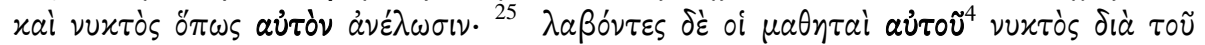

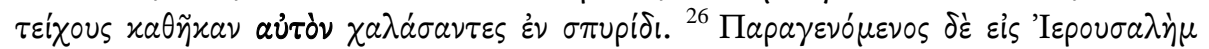

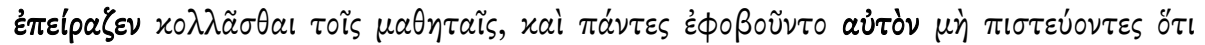

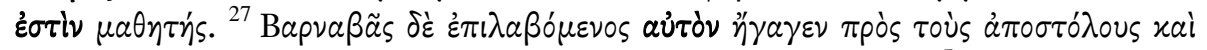

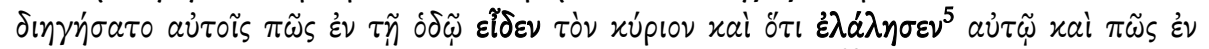

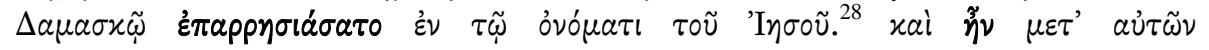

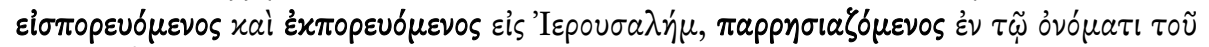

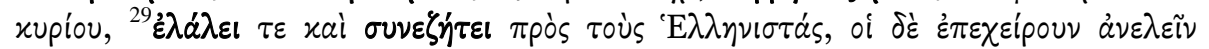

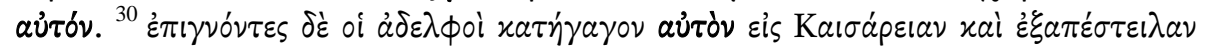

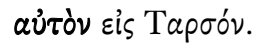

3 Which "apostles" they are is not specified. In Galatians 1:17-18 Paul claims that he only saw Peter and James, the Lord's brother, at this time. FF Bruce, The Acts of the Apostles. Grand Rapids: Eerdmans, 1990:243, sees "apostles" as a generalising plural wherein Peter represents all the apostles. Martin Hengel and Anna Maria Schwemer, Paul between Damascus and Antioch. Grand Rapids: Eerdmans, 1997:138, write dismissively: “At all events the scene in which Luke has Paul appearing 'before the apostles' is unhistorical."

4 Whether this earliest, and most difficult, reading is correct or the reading oi $\mu \alpha \theta \eta \tau \alpha \dot{i} \alpha u \dot{\tau o ́ v}$ is adopted, the referent is still Saul. See Bruce M Metzger, A Textual Commentary on the Greek New Testament. New York: United Bible Societies, 1975:366, and Darrell L Bock, Acts. Grand Rapids: Baker, 2008:367 Additional Note.

5 The translation of $\dot{\varepsilon} \lambda \alpha \dot{\lambda} \eta \eta \varepsilon \nu$ a $\tilde{\tau} \tilde{\omega}$ has also been questioned. Is it "the Lord spoke to Saul" (as in NIV, NLT, ESV, NRSV) or "he (Saul) spoke to the Lord?" The KJV again preserves the ambiguity: "that he had spoken to him," while the NKJV interprets by capitalising the first pronoun: "that He had spoken to him." In the account of Saul's conversion just narrated, both Saul and Jesus speak (Acts 9:4-6). According to CK Barrett, Acts 1-14. London: T\&T Clark, 1994:1.469, "[t] he grammar of the sentence gives no indication of a change of

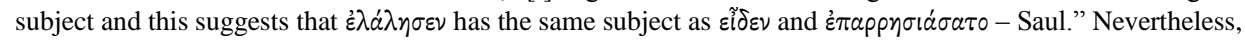
Barrett concedes that "Luke is not so rigidly bound by the rules of grammar as to invalidate the thought that may indicate the initiative of Jesus, who in the conversion story opens the conversation (9.4)." Since Saul is primary referent in this pericope, it is preferable to understand him as the subject, not the Lord. 
${ }^{24}$ But their plot became known to Saul. Day and night they were closely watching the gates so that they might kill him. ${ }^{25}$ But one night his followers took and let him down through the wall by lowering a large basket. ${ }^{26}$ After arriving in Jerusalem he tried to join the disciples, but everyone feared him because they did not think he was a disciple. ${ }^{27}$ But Barnabas took and brought him to the apostles, and he described fully to them how he had seen the Lord on the road and had spoken to him, and how in Damascus he had preached boldly in the name of Jesus. ${ }^{28}$ And he was with them going in and going out of Jerusalem preaching boldly in the name of the Lord. ${ }^{29}$ He began to speak and argue with the Hellenistic Jews, but they attempted to kill him. ${ }^{30}$ When the believers learned this, they brought him to Caesarea and sent him off to Tarsus. ${ }^{6}$

Using a bold font, we see that Saul is last named as an explicit subject or object in verse 24 . In the verses that follow he is the understood pronoun, subject, or object six times before verse 27 where Barnabas is the named subject of the sentence. In the narrative that follows $\delta$ in $\eta^{\prime} \sigma \alpha \tau o$ Saul is again the implied subject or object twelve times, although there is no explicit antecedent identifying Saul except back in verse 24.

So the question still remains whether the subject of $\delta$ in $\eta^{\prime} \sigma \alpha \tau o$ should be understood as Barnabas or Saul. Schnabel translates $\delta i \eta \gamma \dot{\sigma} \sigma \alpha \tau o$ as "explained," which rather suggests the

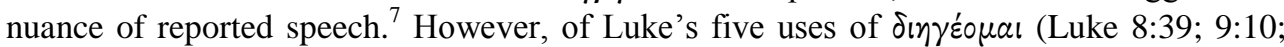
Acts $8: 33 ; 9: 27 ; 12: 17$ ) two of them are used of direct address (Luke 9:10; Acts 12:7) and one implies such (Luke 8:39). Thus a better translation is simply "tell, relate, describe," 8 which is how the contemporary translations cited above translate it. Bock is typical of translators and interpreters who understand Barnabas as the speaker: "There is debate about the subject of the verb here, but that Barnabas speaks up for Saul is the most natural way to read the passage." ${ }^{9}$ However, like recent interpreters he fails to discuss the ambiguity in the Greek text. $^{10}$

Burchard objects to this prevailing view: “According to today's most represented opinion, it is Barnabas, the subject of the previous verb, [who is reporting,] not Paul, the subject of the following, even there, where you, in the then given indirectness of the reporting, cannot find evidence of the mediation of Paul, as it is done by Klein ... then Barnabas may know nothing he could tell, and the characteristics of the report should suggest to the reader to choose as the subject of 'told' the one who alone knew everything." 11 Marshall similarly suggests: "It may be that we should translate the sentence

6 The translations from the Greek texts are my own unless otherwise identified. This translation is more literal since Greek uses pronouns more sparingly than English.

7 Eckhard J Schnabel, Acts. Grand Rapids: Zondervan, 2012:456.

$8 \quad$ Frederick William Danker, A Greek-English Lexicon of the New Testament and other Early Christian Literature. Third edition.; Chicago: University of Chicago Press, 2001:245.

9 Bock, Acts, 369.

10 These others include Mikeal Parsons, Acts. Grand Rapids: Baker, 2008:134. Craig S Keener, Acts. Grand Rapids: Baker, 2013:2:1689. William S Kurz, Acts of the Apostles. Grand Rapids: Baker, 2013:160.

11 Christoph Burchard Der dreizehnte Zeuge. Göttingen: Vanderhoeck \& Ruphrecht, 1970:147-48. German text: "Wer erzählt, ist umstritten. Nach der heute meist vertretenen Meinung ist es Barnabas, das Subjekt des vorhergehenden Verbs, nicht Paulus, das subject der folgenden, auch da, wo man in der dann gegebenen Indirektheit der Berichterstattung nicht ein Anzeichen für Mediatisierung des Paulus findet, wie es Klein tut.... Dann kann Barnabas nichts wissen, was er erzählen könnte, und der Duktus des Berichts dürfte dem Leser nahelegen, als Subjekt zu "erzählte den zu nehmen, der allein Bescheid weiß.” 
differently, so that it was Paul himself who gave his testimony before the apostles." 12 Barrett's objection to making Saul the subject is that "Barnabas's role is reduced to very small proportions." ${ }^{\prime 3}$ But the initial introduction of Barnabas in 4:36-37 was small in comparison to the space given to the entire pericope of 4:32-5:11 in which Ananias and Sapphira feature. Barnabas remains a minor character, so to speak, until the first missionary journey begins in Acts 13.

\section{Eyewitness Testimony in Luke-Acts}

Eyewitness testimony was important for Luke in his two written documents. ${ }^{14}$ Writing about the significance of autoptai, Bauckham states that "there is no doubt, from the total context in Luke-Acts, that it carries the historiographic meaning of people who witnessed firsthand the events of Luke's gospel story." 15 Köstenberger writes similarly, "From the very outset of his Gospel Luke stresses the importance of eyewitness testimony (Lk. 1:1 -4; cf. Acts 1:3)." ${ }^{\prime \prime}$ Just as witnesses introduce primary evidence in Luke's Gospel, for example, Mary (Luke 1:5-80) and Peter (Luke 5:3-8), ${ }^{17}$ witness is an important theme in the book of Acts as well. ${ }^{18}$ As Soards writes, "Indeed, one encounters the theme of Spiritempowered witness from the beginning (1:8) to the end (28:23) of Acts and all along the way, so that the speeches either articulate this witness, attack the witness (as testimony or person), or affirm some dimension of the validity of the witness."19 Jesus' familiar charge to the apostles in Acts 1:8, just mentioned, states that "you will be my witnesses in Jerusalem, and in all Judea and Samaria, and to the end of the earth." The replacement for Judas had to be a witness of the resurrection (Acts 1:22). Speaking to the crowd on the day of Pentecost, Peter declared: "God has raised this Jesus to life, and we are all witnesses of the fact" (Acts 2:32). In his subsequent speeches first in Solomon's stoa (3:15) then twice before the Sanhedrin (Acts 4:20; 5:31), and to Cornelius and household (10:39-41) Peter emphasised that he and the apostles were witnesses of the Jesus events about which they were testifying.

Likewise in his address at the synagogue in Pisidian Antioch Paul made the same point: "And for many days he was seen by those who had traveled with him from Galilee to Jerusalem. They are now his witnesses to our people" (Acts 13:31). Although Paul could

12 I Howard Marshall, Acts. Grand Rapids: Eerdmans, 1980:175 n. 1. Ernst Haenchen, The Acts of the Apostles. Philadelphia: Westminster, 1971:332. likewise comments: "Wikenhauser (Apg. 91) suggests that the subject of $\delta$ in $\dot{\sigma} \sigma \alpha \tau o$ may be Paul!"

13 Barrett, Acts 1-14,1.469, also believes that the "subject of $\delta i \eta \gamma \dot{\gamma} \sigma \alpha \tau$ is usually, and probably rightly taken to be Barnabas."

14 This is also true for the greater Christian community. Papias expresses this sentiment well: "For I did not think that information from books would profit me as much as information from a living and surviving voice." Eusebius Hist. eccl. 3.39.4.

15 Richard Bauckham, Jesus and the Eyewitness. Grand Rapids: Eerdmans, 2006:119.

16 AJ Köstenberger, "Witness," in Dictionary of Jesus and the Gospels. (Ed.) Joel B Green; 2nd edition.; Downers Grove: IVP Academic, 2013:1002.

17 Speaking of Jesus' resurrection appearance to the disciples in Luke 24:39, Peter Bolt, "Mission and Witness," in Witness to the Gospel (ed.) I Howard Marshall and David Petersen (Grand Rapids: Eerdmans, 1998:196), writes: "In language appropriate to the eyewitness, they are asked to see (' $(\delta \varepsilon \tau \varepsilon)$, feel $\left(\psi \eta \lambda \alpha \phi \eta \dot{\sigma} \sigma \tau \tau^{\prime}\right)$, and take note $(\theta \varepsilon \omega \rho \varepsilon \tau \tau \varepsilon)$ of what they observe."

18 The "two" witness motifs that Köstenberger, "Witness," 1002, discusses in Luke's Gospel is also apparent in Acts. For example, in the conversion account of Saul Ananias serves as the second witness to the events that transpired in Damascus (Acts 9:10-18).

19 Marion L Soards, The Speeches in Acts. Louisville, Westminster/John Knox, 1994:199. 
not testify to the earthly ministry of Jesus, his eyewitness testimony about seeing the risen Christ was important for Luke. ${ }^{20}$ In the second retelling of Paul's conversion before the Jewish crowd in Jerusalem Paul recounts the words that Ananias told him: "You will be a witness for him to all people of what you have seen and heard" (Acts 22:15). ${ }^{21}$ Paul then recounts a vision that he received in the temple after his return to Jerusalem (unmentioned in Acts $9^{22}$ ) in which Jesus warned him: "Hurry and depart Jerusalem quickly because they will not accept your testimony about me" (Acts 22:18). ${ }^{23}$ When Paul relates his conversion story before Festus, Agrippa, and Bernice, he states that Jesus himself gave him a charge on the road to Damascus: "For this reason I have appeared to you: to appoint you as a servant and a witness both of what you have seen and what I will show you" (Acts 26:16).

Given the importance of eyewitness testimony for Luke ${ }^{24}$ and the early church, would the apostles have wanted or even allowed Barnabas to recount Saul's conversion account with Saul present beside him? Burchard makes a significant observation: "Moreover, it is according to style that a person who is affected by a supernatural experience should tell it himself." 25 Indeed protocol and civility within eastern Mediterranean culture suggest that Saul himself was the narrator. A comparable narrative situation is found in 2 Kings 8:4 -6 where Gehazi is recounting to the king of Israel Elisha's wondrous works including the raising of the Shunammite woman's son from the dead. At that moment the woman herself appears before the king to appeal for the restoration of her property. Gehazi introduces the woman and her son to the king who then asks her to finish telling the story of her son's resurrection. Since the Shunammite and her son - the subject of Gehazi's story - are now present to provide a firsthand account, the king wants her and not Gehazi to complete the story since she witnessed this event firsthand. Similarly, Saul would have told his own story.

\section{A Fourth Conversion Account}

The description of Saul's conversion in Acts 9:27 is clearly an abridgment of the longer accounts in chapters 9,22 , and $26 .{ }^{26}$ Nevertheless, it shares three features with them. First, on the road to Damascus "he had seen the Lord." Each describes how Paul saw a light (9:3; 22:6; 26:13). In 9:17 and 22:14 it is Ananias who declared that Saul had seen the

20 Eyewitness testimony was also important to Paul as he recounts those who have seen the resurrected Lord including himself as "last of all he appeared ( $\omega \phi \theta \eta)$ to me, as to one with an untimely birth" (1 Cor. 15:8).

21 These words of Ananias are unmentioned in the initial account in chapter 9, although Jesus' statement to him about Saul, "This man is my chosen instrument to carry my name before the Gentiles and kings and the people of Israel" (Acts 9:15), is functionally equivalent. In the third account in Acts 26:17-18 Jesus himself gives the call.

22 A narrative feature of Luke is to add details to subsequent retellings of an event, which has caused some scholars to question their historicity rather than recognise this as a literary device of ancient storytellers and historiographers; see Keener, Acts, 2:1598.

23 In his conversation with the Lord in Acts 22:20 Paul mentions to his shame that he was an eyewitness to an event that he would rather forget: the murder of Jesus' witness Stephen.

24 Speaking about the well-known "we" passages in Acts in which the author purports to be an eyewitness, F Scott Spencer, Journeying through Acts: A Literary-Cultural Reading. Peabody: Hendrickson, 2004:172-73, writes: "Whatever the historical cause of introducing 'we' at this juncture (which in the absence of synoptic sources remains indeterminable), the rhetorical effect injects a fresh sense of both intimacy and legitimacy into the narrative."

25 Burchard, Der dreizehnte Zeuge, 147-48; German text: "Im übrigen ist es stilgemäß, daß eine von einem übernatürlichen Erlebnis betroffene Person dieses selbst erzählt.”

26 For a detailed discussion of the similarities and perceived differences in these three versions using a comparison chart, see Ben Witherington, Acts. Grand Rapids: Eerdmans, 1998:303-15. 
Lord/Righteous One, while in 26:16 Jesus himself announced his appearance to Saul. Second, he spoke to the Lord $(9: 5,22: 8 ; 26: 15) .{ }^{27}$ And third, he had spoken boldly in

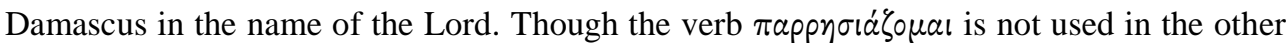
three accounts, Luke uses it five in other places in Acts to characterise Paul's preaching as bold and fearless: Jerusalem (9:28), Pisidian Antioch (13:45), Iconium (14:3), Ephesus $(19: 8)$ and Caesarea $(26: 26){ }^{28}$

An observation often made in commentaries on Acts is that Luke records three accounts of the conversions of Cornelius and of Saul. For example, Keener writes: "This is a strategic section of Acts, which includes two events that Luke ultimately reports three times: the conversions of Paul (9:1-8; 22:4-16; 26:6-18) and Cornelius (10:1-48; 11:5-15; 15:7-9)." 29 Why such repetition? Haenchen affirms: "Luke employs such repetitions only when he considers something to be extraordinarily important and wishes to impress it unforgettably on the reader." 30 Although unstated by Luke, there may be an assumption that "a matter must be established by the testimony of two or three witnesses" (Deut. 19:15). ${ }^{31}$

Nevertheless, a significant observation to make here is that Acts 9:27 provides a fourth account of Saul's conversion regardless of whether Barnabas or Paul is the speaker. Like Peter's third retelling of the conversion of the Gentiles at the Apostolic Council (Acts 15:7-9), this fourth retelling of Saul's conversion is brief. Apart from the initial narration of each conversion, either Peter or Paul is the speaker for subsequent recountings of these conversions. This observation lends further support for the interpretation that Saul is likewise the speaker in 9:27.

\section{Conclusion}

This article has demonstrated that the preferred subject of Acts 9:27 is Saul, not Barnabas, as is stated in many English translations. Various arguments have been offered to show that the ambiguity of the sentence's unstated subject is better resolved as a reference to Saul. The significance of eyewitness testimony in Luke-Acts suggests that individuals recounted their own experiences rather than have others tell the story. Thus in this case Saul recounted his conversion story to the apostles rather than Barnabas. This account provides a fourth telling of Saul's conversion in Acts, an observation previously overlooked by most commentators.

See note 5 regarding the translation issues behind this interpretation.

28 These bold proclamations, as Bruce, The Book of Acts, 243, suggests, were "perhaps under the Holy Spirit's impulsion." Apollos is likewise characterised as someone who spoke fearlessly (Acts 18:26)

29 Keener, Acts, 2:1598; see note 7. Witherington, Acts, 303 likewise notes that there are three full treatments of Paul's conversion, but in his discussion of 9:27 (326) he fails to mention the brief treatment there or Barnabas's role in it.

30 Haenchen, The Acts of the Apostles, 327. JM Everts, "Conversion and Call of Paul," in Dictionary of Paul and his Letters (eds.) Gerald F Hawthorne and Ralph P Martin; Downers Grove: InterVarsity, 1993:158-59, likewise writes, "The fact that the conversion/call account occurs three times suggests that this event has major significance for Luke's narrative."

31 Paul himself cites this verse, not in the context of a capital crime (Deut 17:6; cf. Heb 10:28), but rather warns of corrective measures to the Corinthians on his third visit (2 Cor 13:1; cf. Matt 18:16; 1 Tim 5:19). For Paul's use here, see Frank J Matera, II Corinthians. Louisville: Westminster/John Knox, 2003:305-6. 